ks. Bogusław Mielec

\title{
OSOBOWOŚĆ JANA PAWŁA II W ZAPOMNIANYM TEKŚCIE PROFESOR HANNY ŚWIDY-ZIEMBY
}

\section{Wstęp}

Bogata i wielowymiarowa działalność Karola Wojtyły - Jana Pawła II pozostaje $\mathrm{w}$ ścisłej korelacji z jego osobowością. A to z racji jej religijnego i humanistycznego charakteru. Pierwszy wymiar wymaga osobistego świadectwa. W tej dziedzinie można być nauczycielem tylko wtedy, gdy wcześniej jest się świadkiem sacrum ${ }^{1}$. Analogicznie rzecz wygląda, jeśli bierze się pod uwagę humanistyczny charakter dziedzictwa polskiego papieża. Jawi się ono jako specyficzny zapis integralnego rozwoju samego Karola Wojtyły - Jana Pawła II. Bowiem on „sam był w nieustannym procesie dorastania do osiągnięcia spójności myśli, słowa i czynu, a aktywności i zadania, których się podejmował oraz sytuacje, które go spotykały, potrafił wykorzystać dla własnego wszechstronnego rozwoju"2.

Dlatego był nie tylko teoretykiem, ale i praktykiem chrześcijańskiego humanizmu, przekonanym o jego dynamicznym, rozwojowym potencjale. Nieustannie szukał filozoficznych, teologicznych i artystycznych środków wyrazu dla przekonania, iż człowiek jest „dany” i „zadany” sobie. Na przykład w napisanym u schyłku życia Liście do artystów ujął to w następujący sposób: „Zadaniem każdego człowieka jest być twórcą własnego życia: człowiek ma uczynić z niego arcydzieło sztuki”3. W tym sensie każdy człowiek jest „artystą, który w tym, co tworzy „wyraża swoją osobowość"4. Papież był tego wybitnym przykładem zarówno w swojej twórczości, jak i różnorodnej działalności. Nie można jej zatem zrozumieć, jeśli

1 Por. Jan Paweł II, enc. Redemptoris missio, Watykan 1990, nr 42.

2 D. Żukowska-Gardzińska, Wprowadzenie, [w:] Jan Paweł II. Miara wielkości człowieka, red. D. Żukowska-Gardzińska, Warszawa 2020, s. 11-12.

3 Jan Paweł II, List do artystów, Watykan 1999, nr 2.

4 Jan Paweł II, List do artystów, dz. cyt. 
pomija się kwestię osoby i osobowości autora. Na tę koherencję wskazywał dyskretnie, gdy stwierdzał: „Chcą zrozumieć mnie z zewnątrz, tyle, że mnie da się zrozumieć tylko od wewnątrz"

Dlatego, zdaniem profesora Stanisława Grygiela, można określić go mianem „profesora-mistrza”. Mistrz zaś „objawia uczniom samego siebie” i dlatego „musi być przezroczysty moralnie, tak żeby uczniowie mogli przez niego dostrzec Inność Transcendencji”'.

Wszystko to potwierdza tezę o istotnej korelacji dzieła i osoby polskiego papieża. Wyznacza również dwie drogi interpretacyjne jego myśli i dokonań. Za Krzysztofem Dybciakiem, który określa je w odniesieniu do literackiej twórczości Jana Pawła II, można zastosować te dwa modele interpretacyjne do całości papieskiego dzieła. Pierwszy koncentruje się na różnorodnej analizie poszczególnych utworów czy konkretnych dokonań, jednak bez odniesienia do osoby autora. Drugi zaś traktuje wyniki tej analizy jako „semiotyczny materiał dostarczający wiedzy o osobowości jednej z czołowych postaci”” naszych czasów. Można ten sposób interpretacji nazwać poszukiwaniem „genealogii osoby autora” zapisanej w jego dziełach.

W niniejszym tekście wybieramy tę drugą drogę, przypominając charakterystykę osobowości Jana Pawła II dokonaną przez profesor Hannę Świdę-Ziembę po papieskiej pielgrzymce do Polski w czerwcu 1979 roku. Znajduje się ona w wydanej prawie czterdzieści lat temu książce pt. Papież $i M y^{8}$ i raczej rzadko cytowanej przez badaczy pontyfikatu. Wspomniany tekst jest krótki, lecz odznacza się takimi intelektualnymi i moralnymi walorami, że konieczne wydaje się przypomnienie biografii jego autorki oraz jej światopoglądowej autoprezentacji. Temu poświęcimy pierwszy punkt artykułu. W następnych dwóch paragrafach znajdzie się charakterystyka Jana Pawła II jako intelektualisty, co dla prof. Hanny Świdy-Ziemby okazało się inspiracją do przeprowadzenia głębokiego wglądu w jego złożoną osobowość. Ten ostatni fragment jej wypowiedzi będzie miał kluczowe znaczenie, i, miejmy nadzieję, stanowić będzie uzasadnienie celowości całego artykułu.

${ }_{5}$ G. Weigel, Lekcje nadziei. Moje niespodziewane życie ze świętym Janem Pawłem II, tłum. K. Rybicka, Kraków 2019, s. 135.

6 S. Grygiel, Mistrz-uczeń, [w:] Jan Paweł II. Miara wielkości człowieka, red. D. ŻukowskaGardzińska, Warszawa 2020, s. 23; por. Z. Zarębianka, Karol Wojtyła jako nauczyciel życia wewnętrznego. Zarys problematyki badawczej, [w:] Jan Paweł II. Posługa myślenia, red. J. Kupczak OP, D. Radziechowski, Kraków 2011, s. 43-52.

7 K. Dybciak, Wprowadzenie, [w:] Pisarstwo Karola Wojtyty-Jana Pawła II w oczach krytyków i uczonych. Antologia, red. K. Dybciak, Warszawa 2019, s. 13.

${ }^{8}$ H. Świda-Ziemba, O wizycie papieża - obserwacje, przeżycia, refleksje, [w:] Papież i My, Warszawa 1981, s. 367-371. 


\section{Profesor Hanna Świda-Ziemba - dane biograficzne i bibliograficzne}

Hanna Świda-Ziemba (1930-2012) to wybitna polska uczona, socjolog, nauczyciel akademicki, działaczka opozycji w PRL, internowana w stanie wojennym w 1981 r. Studia z zakresu socjologii na Uniwersytecie Łódzkim ukończyła w 1952 roku, stopień naukowy doktora uzyskała osiem lat później (książkowa wersja doktoratu pt. Młodzież licealna: analiza wybranych klas warszawskich w latach 1956-58, Warszawa 1963, została ocenzurowana, gdyż wnioski okazały się niepoprawne politycznie). W 1969 habilitowała się na podstawie rozprawy Osobowość jako problem pedagogiki, Wrocław 1970. Dopiero w 1995 otrzymała tytuł profesora nauk humanistycznych. Od 1954 związana była zawodowo z Uniwersytetem Warszawskim. Wchodziła w skład prezydium Polskiej Akademii Nauk, w której współtworzyła Instytut Nauk Humanistycznych i Społecznych. Wykładała także w Szkole Wyższej Psychologii Społecznej. Opublikowała szereg prac naukowych, głównie z zakresu socjologii wartości, młodzieży i analizy systemów totalitarnych. Do najważniejszych z nich należą: Stalinizm i społeczeństwo polskie, Warszawa 1991, Człowiek wewnętrznie zniewolony. Mechanizmy i konsekwencje minionej formacji - analiza psychologiczna, Warszawa 1997, Młodzi w nowym świecie, Warszawa 2005, Młodzież PRL. Portrety pokoleń w kontekście historii, Kraków 2010.

W latach 1991-1993 wchodziła w skład Trybunału Stanu. W 2003 r. otrzymała Medal „Zasłużony dla Tolerancji”, a w 2011 r. krakowską „Nagrodę im. Jana Długosza" za ostatnią swoją książkę pt. Młodzież PRL. W tym samym roku została odznaczona Krzyżem Komandorskim Orderu Odrodzenia Polski. Dominik Czapigo z Ośrodka Karta poświęcił jej książkę pt. Uchwycić życie. Wspomnienia, dzienniki i listy 1930-1989, Warszawa 2018, w której zamieścił wybór jej wspomnień, prywatnych listów i dziennika. Pozycja ta pozwala na głębsze poznanie życia i osobowości Hanny Świdy-Ziemby.

Przedstawione wyżej dane biograficzne i bibliograficzne naszej autorki świadczą o jej naukowych kompetencjach w zakresie psychologii, socjologii i pedagogiki. Natomiast fakt publikacji tekstu, będącego przedmiotem niniejszego artykułu, w tolerowanej przez ówczesne władze komunistyczne prywatnej katolickiej oficynie „Biblioteka Więzi”, jest dowodem na jej wysokie walory moralne. Należy bowiem przypomnieć, że w ówczesnych realiach totalitarnego państwa, był on wyrazem sporej odwagi, osobistej wolności i uczciwości intelektualnej. Dla pracownika naukowego $\mathrm{z}$ tytułem docenta, a więc przed profesurą, był to akt ryzykowny, zważywszy, że jak sama pisze w tekście, „wypowiedź ta ma charakter intymny 
i osobisty, gdyż właśnie w ten sposób przeżyłam wizytę papieża Jana Pawła II

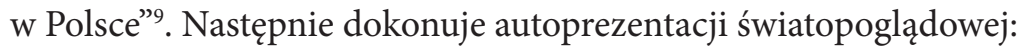

nie należę do grona ludzi wierzących, choć nie jestem ateistką. Wiarę utraciłam 32 lata temu, będąc uczennicą szkoły średniej i od tego czasu przez długie lata nie odczuwałam ani potrzeb, ani zainteresowań problematyką religii. Sprawy te uznałam za nierozstrzygalne ze swej istoty, a zatem nie mieszczące się w żadnej formie w moim horyzoncie światopoglądowym i nieważne w osobistym życiu ${ }^{10}$.

W kolejnych akapitach autorka pisze o trzech doświadczeniach, które okazały się szczelinami w jej religijnym indyferentyzmie. Pierwszą był pontyfikat Jana XXIII (1958-1963) i Sobór Watykański II (1962-1965), dzięki którym uznała, że „Kościół ma szansę odegrania istotnej roli we współczesnym świecie dzięki odnowie i akcentowaniu tych wartości chrześcijańskich, które stały się uniwersalnymi wartościami moralnymi oraz dzięki nawiązaniu dialogu i otwarciu się na «świat pozakatolicki»" ". Drugim, istotnym dla autorki przeżyciem, były „doświadczenia osobiste i społeczne oraz towarzysząca im refleksja”, które sprawiły, iż zaczęła „dostrzegać istotną i pozytywną funkcję wiary dla życia człowieka, tak w wymiarze prywatno-osobistym, jak i ogólnospołecznym"12. Autorka nie wyjaśnia, o jakie doświadczenia chodzi, ale podkreśla, że nadal pozostawała zewnętrznym obserwatorem katolicyzmu ,jako człowiek niewierzący.” Trzecim, mocnym katalizatorem zmiany w podejściu do katolicyzmu, był wybór Jana Pawła II, który wywołał w niej wzruszenie, uniesienie i radość jako Polki. Wydarzenie to sprawiło, iż zapragnęła dotrzeć do naukowych prac Karola Wojtyły z racji swych „zainteresowań problematyką aksjologii, psychologii osobowości i filozofii człowieka”'13.

\section{Karol Wojtyła jako intelektualista}

Znamienne jest to, że dla Hanny Świdy-Ziemby wspólnota zainteresowań stała się okazją do bliższego „spotkania” z myślą Karola Wojtyły, co w przyszłości pociągnie za sobą zaciekawienie jego osobą. Wspomina zatem, iż „po wielu perypetiach udało mi się pożyczyć dzieło fundamentalne dla jego twórczości - Osoba i czyn"14. Dla wyjaśnienia dodajmy, że książka Osoba i czyn została wydana

9 H. Świda-Ziemba, O wizycie papieża, dz. cyt., s. 367.

${ }^{10} \mathrm{H}$. Świda-Ziemba, O wizycie papieża, dz. cyt., s. 367.

${ }^{11}$ H. Świda-Ziemba, O wizycie papieża, dz. cyt., s. 367.

${ }^{12}$ H. Świda-Ziemba, O wizycie papieża, dz. cyt., s. 367.

${ }^{13} \mathrm{H}$. Świda-Ziemba, O wizycie papieża, dz. cyt., s. 367.

${ }^{14}$ H. Świda-Ziemba, O wizycie papieża, dz. cyt., s. 368. 
w 1969 r. w niewielkim nakładzie przez niszowe kościelne wydawnictwo Polskiego Towarzystwa Teologicznego w Krakowie; była zatem nieznana szerokiemu gronu odbiorców i trudno dostępna. Sytuacja ta była spowodowana „odgórną”, motywowaną ideologicznie marginalizacją pracy naukowej polskich katolików. Służyły temu zarówno wszechobecna, prewencyjna cenzura, trudność w uznaniu przez państwo stopni naukowych uzyskanych na kościelnych uczelniach, jak i administracyjne decyzje, ograniczające przydział papieru dla zaledwie tolerowanych kościelnych wydawnictw.

Wróćmy jednak do ważkich uwag j autorki, która wspomina następnie, iż

lektura tej książki wywarła na mnie silne wrażenie. Poruszyła mnie głębia, wielowarstwowość, klarowność i uniwersalność zawartych tam refleksji. Zaprezentowana koncepcja człowieka w ogólnej intencji była zgodna z moimi własnymi intuicjami i poglądami, co dowodzi, że może ona zostać zaakceptowana również przez ludzi niewierzących. $Z$ drugiej strony przeprowadzone tam analizy stały się dla mnie źródłem wielorakich refleksji, w istotny sposób wzbogaciły i przeorganizowały mój dotychczasowy punkt widzenia, ukazując mi problematykę istoty człowieka (a więc i własnego życia) w nowej perspektywie. W jakimś sensie poznanie tego dzieła uważam za przełom w mym życiu osobistym i intelektualnym. Pewne tezy budziły jednak we mnie opór, zrozumiały u człowieka o innym światopoglądzie. Rodziły się pytania i głęboka potrzeba konfrontacji i rozmowy $\mathrm{z}$ autorem ${ }^{15}$.

Mamy zatem do czynienia z intelektualnym spotkaniem czytelnika z autorem, które zawsze jest relacją wzajemną, najpierw wokół obiektywnych treści, a następnie w wymiarze międzyosobowym. Na taki właśnie intelektualno-relacyjny zamiar Karola Wojtyły wskazuje George Weigel, gdy zauważa, że:

Pisząc Osobę i czyn, Karol Wojtyła przeniósł swoje koncepcje na nową płaszczyznę, usiłując stworzyć w pełni rozwiniętą filozofię osoby ludzkiej, w której jego interlokutorami byli czytelnicy. Pomimo niezwykłych wymagań, jakie książka stawia czytelnikowi, Osoba i czyn jest faktycznie zaproszeniem do rozmowy. Tak ja odczytuję ludzką kondycję - zdaje się mówić Wojtyła - Jak ma się to do twojego własnego doświadczenia? ${ }^{16}$

Wynika z tego, że Świda-Ziemba wnikliwie i trafnie odczytała personalistyczny sens tej najważniejszej filozoficznej książki Karola Wojtyły. Stanowi ona bowiem zapis doświadczenia bycia sobą i współbycia razem z innymi; dlatego w gruncie

${ }^{15}$ H. Świda-Ziemba, O wizycie papieża, dz. cyt., s. 368.

${ }^{16}$ G. Weigel, Świadek nadziei. Biografia Jana Pawła II, tłum. M. Tarnowska, J. Piątkowska, D. Chylińska, J. Illg, R. Śmietana, Kraków 2000, s. 225. 
rzeczy jest zachętą do wspólnego myślenia o człowieku, co wskazuje na jej dialogiczny charakter.

Kolejnym wnioskiem płynącym z wnikliwej lektury Osoby i czynu jest przekonanie badaczki, iż Karol Wojtyła jest twórcą jednej z nielicznych na gruncie polskim filozofii człowieka w źródłowym znaczeniu tego słowa ${ }^{17}$. Oznacza to, iż jej percepcja wymaga uczestnictwa, a nie jedynie znajomości poszczególnych wątków tej filozofii. Używając terminologii zaczerpniętej z Osoby i czynu, nie chodzi tu jedynie o „poznanie obiektywizujące”, ale o świadomość, która odzwierciedla i przeżywa przyswajane treści. Taka recepcja dzieła rodzi pragnienie osobowego spotkania z jego autorem, o czym wspomina Świda-Ziemba, gdy pisze, iż „oczekując wizyty papieża Jana Pawła II w Polsce”, oczekiwała „nie tylko Głowy Kościoła katolickiego, ale także autora książki Osoba i czyn"18. Jest to kolejna, godna podkreślenia, trafna intuicja polskiej uczonej. Wszak książka ta była jednym $\mathrm{z}$ istotnych źródeł wielu wątków późniejszych wypowiedzi i działań Karola Wojtyły już jako Jana Pawła $\mathrm{II}^{19}$.

Wydaje się, że komentarze te zyskają swoje uzasadnienie w ostatnim punkcie naszego tekstu, w którym przedstawimy zarówno zapis własnych przeżyć autorki, jak i jej wnikliwy wgląd w osobowość papieża. Właśnie ta „nieobojętność” na związek treści i osoby uderza w refleksji polskiej uczonej. Dlatego można ją traktować jako trwały wkład w wyjaśnienie fenomenu recepcji całej twórczości Jana Pawła II. W tym sensie osobiste refleksje naszej autorki jako czytelniczki Osoby i czynu oraz uczestniczki pierwszej pielgrzymki do Polski okazują się szczególnie wnikliwe i trafne.

\section{Osobowość Jana Pawła II}

W ostatniej części tego tekstu przedstawimy dwa najważniejsze fragmenty refleksji profesor Hanny Świdy-Ziemby. Pierwszy będzie prezentacją jej rzetelnego wglądu we własne doświadczenie związane z pierwszą papieską pielgrzymką do Polski. W drugim skoncentrujemy się na dokonanej przez nią oryginalnej charakterystyce osobowości Jana Pawła II.

Na początku autorka dokonuje starannej retrospekcji podmiotowej i przedmiotowej, stwierdzając, że

${ }^{17}$ Por. H. Świda-Ziemba, O wizycie papieża, dz. cyt., s. 368.

${ }^{18}$ H. Świda-Ziemba, O wizycie papieża, dz. cyt., s. 368.

${ }^{19}$ Por. R. Buttiglione, Kilka uwag o sposobie czytania „Osoby i czynu”, [w:] K. Wojtyła, Osoba i czyn oraz inne studia antropologiczne, red. T. Styczeń i in., Lublin 1994, s. 23-37. 
Moje przeżycia związane z pielgrzymką papieża Jana Pawła II po Polsce były „wstrząsem psychicznym”, jednym z najsilniejszych, jakich doznałam w życiu. Na okres dziewięciu dni zostałam jakby przeniesiona w inny i nieznany wymiar rzeczywistości w wymiar sacrum. Tych odczuć nie potrafię sobie wytłumaczyć. Jak to jest możliwe, by nie wierząc w prawdy religii, nie uznając Kościoła - móc zarazem w ten właśnie sposób przeżywać wizytę papieża? Odnoszę w tej chwili wrażenie, jakbym emocjonalną intuicją - o której pisze Scheler - odczuła w ciągu tych dni wyższość wartości religijnych. Jest to wyłącznie odczucie. Lecz dość silne i trwałe, by jednocześnie zrodziło we mnie świadomość, że mój własny horyzont poznawczy jest ograniczony, że poza jego linią znajduje się coś, do czego nie mam dostępu. Nigdy co prawda - jako relatywistka - nie sądziłam, że to mój światopogląd jest prawdziwy, a inne fałszywe; uważałam go po prostu za jeden z możliwych punktów widzenia. Ponieważ jednak i inne światopoglądy traktowałam podobnie, uznawałam własny kąt widzenia oglądu rzeczywistości za wystarczający dla mnie i - w wymiarze subiektywności - pełny. Teraz natomiast uległo to zmianie. Żywo odczuwam istnienie niedostępnych tajemnic poza granicami mego subiektywnego świata. Granic tych nie przekroczę, ale ich istnienie jest już stale obecne w mej świadomości ${ }^{20}$.

Warto raz jeszcze podkreślić rzetelność intelektualną i uczciwość moralną autorki, która w sposób otwarty pisze o tak osobistych doznaniach, a jednocześnie jako osoba dojrzała i wykształcona, poszukuje racjonalizacji własnych doświadczeń. W tym celu podejmuje próbę całościowego wglądu w to doświadczenie, co jest zbieżne z główną tezą filozoficzną Karola Wojtyły. Uważa on bowiem, że interpretacja doświadczenia człowieka wymaga zarówno filozofii bytu (ontologii i metafizyki), jak i filozofii świadomości (fenomenologii). Pierwsza uznaje istnienie rzeczywistości zewnętrznej wobec ludzkiej świadomości, druga zaś podkreśla wagę interioryzacji tej rzeczywistości w tzw. „wewnętrznym świecie” człowieka. Jak stwierdza Rocco Buttiglione:

ludzkie doświadczenie przebiega zatem „między światem rzeczywistości zewnętrznej (i prawdy wiecznej) a wewnętrznym światem naszych postaw afektywnych, który właściwie nie tyle poznaje, ile raczej uznaje prawdę poznaną, użyczając jej mocy, emocjonalnego kolorytu oraz intensywności ${ }^{21}$.

W taki właśnie sposób autorka opisuje też osobiste doświadczenie pierwszej pielgrzymki i „spotkania” z osobą Jana Pawła II. Racjonalizacja tego doświadczenia nie oznacza dla niej wyparcia subiektywnych przeżyć, nawet jeśli wykraczają

${ }^{20}$ H. Świda-Ziemba, O wizycie papieża, art. cyt., s. 368-369.

${ }^{21}$ R. Buttiglione, Kilka uwag o sposobie czytania „Osoby i czynu”, dz. cyt., s. 13. 
one poza dotychczasowe granice jej horyzontu poznawczego. Wszak brak osobistego przeżycia np. religijnego wymiaru rzeczywistości nie oznacza jego nieistnienia. Jednak w tym przypadku jest on zapośredniczony przez doświadczenie „spotkania” człowieka religijnego, jakim jest dla naszej autorki Jan Paweł II. Właśnie w tym newralgicznym punkcie autorka przyznaje rację metodologii przyjętej przez autora Osoby i czynu. Dąży on bowiem do scalenia obiektywnego i subiektywnego wymiaru doświadczenia. Jego zdaniem ,jakakolwiek absolutyzacja jednego z dwóch aspektów doświadczenia człowieka musi ustąpić wobec potrzeby ich wzajemnej relatywizacji” ${ }^{22}$. W przedstawionym wyżej fragmencie tekstu profesor Świdy-Ziemby można dostrzec to wzajemne odniesienie obu aspektów doświadczenia, przez co wykracza on poza paradygmat scjentyzmu, z jego brakiem rozróżnienia między poznaniem rzeczy a doświadczeniem człowieka. Właśnie nauki społeczne, będące przedmiotem specjalizacji naszej uczonej, jak psychologia, socjologia i pedagogika, są szczególnie wyczulone na błąd redukowania człowieka jedynie do przedmiotu badań na wzór nauk przyrodniczych.

Przejdźmy teraz do kluczowego fragmentu, który jest kolejnym dowodem na wysoki stopień kompetencji profesor Świdy-Ziemby. Oto bowiem nasza autorka dokonuje próby charakterystyki osobowości człowieka, za pośrednictwem którego doświadczyła tak znamiennego poszerzenia i pogłębienia własnego podejścia do rzeczywistości. Fakt istnienia takiego związku wyraża ona w następujący sposób: „Istotnym źródłem i przyczyną tego wrażenia jest to, że była to wizyta papieża Polaka o tak niezwykłej i wręcz niewiarygodnej osobowości, a zarazem o takim darze promieniowania"23. Wydarzenie, którego głównym bohaterem był Jan Paweł II, wywołuje zatem zainteresowanie jego osobowością. Użycie terminu „osobowość" wskazuje na zamiar wykorzystania własnych kompetencji ludzkich i zawodowych. Wszak „osobowość” to pojęcie ukształtowane i zdefiniowane w ramach psychologii, socjologii oraz pedagogiki, czyli dyscyplin naukowych, w których się specjalizowała. Oznacza ono zespół stałych cech psychicznych i mechanizmów wewnętrznych, które warunkują postawy i zachowania ludzi w ich interakcjach ze środowiskiem, a jednocześnie wyróżniają ich jako odrębne jednostki. Bazując na swej naukowej wiedzy, a jednocześnie egzystencjalnym doświadczeniu, autorka twierdzi, że

Niewiarygodność osobowości Jana Pawła II polega na tym, że łączy On w sobie właściwości, które z reguły się wykluczają.

${ }^{22}$ K. Wojtyła, Osoba i czyn oraz inne studia antropologiczne, red. T. Styczeń i in., Lublin 1994, s. 67.

${ }^{23}$ H. Świda-Ziemba, O wizycie papieża, dz. cyt., s. 369. 
Intelektualistę tak wysokiej klasy cechuje na ogół wewnętrzna niepewność w działaniu. Intelektualista nie jest zazwyczaj człowiekiem mocnym i zdecydowanym. Przeszkadza mu w tym umysłowa zdolność dostrzegania wielorakich racji, stająca się źródłem wahań.

Dla intelektualisty operującego pojęciami o wysokim stopniu abstrakcji - ten styl myślenia staje się w tym stopniu naturalnym sposobem bycia”, że utrudnia mu nawiązanie kontaktu i znalezienie wspólnego języka z tak zwanymi „zwykłymi ludźmi”.

Człowiek wymagający wobec siebie i innych w zakresie postaw moralnych - staje się z natury rzeczy kostyczny i surowy, trudno mu zdobyć się (choćby w imię zasad o to się starał) na serdeczność, ciepło, tolerancję i bezpośredniość.

Człowiek obcujący ciągle wewnętrznie z patosem wyższych wartości, zdolny sugestywnie wytworzyć wśród ludzi klimat napięcia i autentycznych wzruszeń z tzw. „nadprzyrodzonego wymiaru” - nie umie zarazem w sposób naturalny być wesoły dowcipny, swobodny i ludzki.

Dotychczasowe moje obserwacje potwierdziły wykluczanie się tych cech. Można spotkać różnorodnych ludzi wartościowych, są oni jednak zarazem jakby jednowymiarowi. Sądziłam dotąd, że są to uniwersalne prawa psychologii człowieka, rozumiejąc zarazem dobrze mechanizm ich funkcjonowania.

Stąd poczucie niezwykłości w kontakcie z Papieżem Janem Pawłem II. Łącząc w sobie silnie zarysowane cechy psychologicznie sprzeczne, wywołuje On jednocześnie wrażenie maksymalnej naturalności i wewnętrznej harmonii. Współistnienie tych cech, zadziwiające „w ogóle”, przestaje być zadziwiające w tym człowieku.

Autor Osoby i czynu, intelektualista zdolny do tak głębokich, wnikliwych i drobiazgowych analiz, że już samo to winno Go skłaniać wyłącznie do umysłowej kontemplacji, jawi się nagle jako człowiek o sprężonej, sugestywnej sile wewnętrznej, promieniując zarazem prostotą, serdeczności i dobrocią, nawiązując osobisty i bezpośredni kontakt z milionowym tłumem.

W odczuciu ludzi podobnych do mnie stanowi On naturalne u o s o s obie nie wartości chrześcijańskich jako żywy człowiek, a nie jako Najwyższy Dostojnik Kościoła. Jego osobowość była nam bezpośrednio dostępna, przekraczając ramy jakiejkolwiek instytucji, choć Instytucję Kościoła w pełnym wymiarze zarazem reprezentował ${ }^{24}$.

Bogactwo treści uzasadnia tak obszerną prezentację tego fragmentu refleksji profesor Hanny Świdy-Ziemby. Jest też dowodem słuszności opinii, że „w pierwszych kontaktach z innymi następuje odkrycie tzw. cech centralnych osobowości” ${ }^{25}$.

${ }^{24}$ H. Świda-Ziemba, O wizycie papieża, dz. cyt., s. 369-370.

${ }^{25}$ J. Makselon, Społeczny kontekst funkcjonowania człowieka, [w:] Psychologia dla teologów, red. J. Makselon, Kraków 1990, s. 224. 
W przyjętej przez naszą autorkę perspektywie psychologiczno-socjologicznej, centralną dominantą osobowości papieża jest połączenie zazwyczaj sprzecznych właściwości intelektualnych i moralnych. Fakt ten wywołuje zdziwienie, stając się równocześnie przedmiotem jej zainteresowania. Jednak ze względu na przyjętą konwencję opisowo-historyczną tekstu napisanego jako osobiste wspomnienie, nie ma w nim miejsca na ujęcie problematyczne. A zatem na podjęcie próby wyjaśnienia przyczyn tego intrygującego zjawiska, jakim jest harmonijna i spójna osobowość papieża, łącząca przeciwstawne cechy psychiczne. Autorka wskazuje jednak kierunek dalszych badań, podkreślając (rozstrzelonym drukiem), iż chodzi tu o „naturalne uosobienie wartości chrześcijańskich”. Każdy z tych terminów ma swoje istotne znaczenie, gdyż odsyła do kolejnych poziomów interpretacji fenomenu człowieka. Psychiczne wrażenie autentycznej harmonii stawia pytanie o możliwość takiego zjawiska; ono zaś domaga się odpowiedzi, poszukiwanej w filozoficznej antropologii, etyce i teologii Jana Pawła II.

Warto $\mathrm{w}$ tym miejscu przypomnieć, że badanie oryginalnego procesu personalizacji człowieka było głównym przedmiotem antropologii filozoficznej i teologicznej Karola Wojtyły - Jana Pawła II. Był on wszak twórcą tzw. „antropologii adekwatnej", w której punktem wyjścia jest doświadczenie samego siebie oraz innych ludzi ${ }^{26}$, przy czym oba te typy doświadczeń z jednej strony są niewspółmierne, jedyne i niepowtarzalne, a $\mathrm{z}$ drugiej, nakładają się na siebie. Można zatem założyć, iż wojtylańska filozofia człowieka wyrasta zarówno z doświadczenia własnej personalizacji, jak i z prób zrozumienia tego procesu u innych ludzi. Jest zatem kluczem do genealogii osobowej jej twórcy.

Dlatego wypracowane przez Karola Wojtyłę kategorie antropologiczne mogą być pomocne w wyjaśnianiu złożonej osobowości jego samego. Wśród nich należy wymienić m.in. „świadomą sprawczość”, „samostanowienie, samopanowanie i samoposiadanie”, „transcendencję poziomą i pionową" czynu ludzkiego, czyli jego znaczenie osobowotwórcze i moralne, a także zdolność do integracji dynamizmów psychosomatycznych. Wszystkie one ujawniają istnienie duchowego podmiotu, zdolnego do potrójnego przekraczania siebie. Chodzi tutaj o autotranscendencję, wyjście w stronę drugiego człowieka oraz Boga ${ }^{27}$. Podczas tego procesu personalizacji następuje integralny rozwój człowieka, w którym centralne miejsce zajmują wartości moralne.

Wspomina o nich także nasza autorka i w ten sposób odsyła do etycznego wymiaru harmonijnej osobowości papieża. Za kryterium właściwego poznania i realizacji wartości uznaje on prawdziwe dobro osoby, dzięki czemu człowiek staje się

${ }^{26}$ Por. K. Wojtyła, Osoba i czyn oraz inne studia antropologiczne, dz. cyt., s. 53-54.

${ }^{27}$ Por. M. Zboralska, Przekraczanie siebie jako podstawa antropologii teologicznej Karola Wojtyły-Jana Pawła II, Kraków 2012, s. 237. 
dobry lub zły w znaczeniu moralnym ${ }^{28}$. Kryterium to pomaga poznać właściwą treść wszelkich ludzkich wartości i urzeczywistniać je poprzez sprawności psychomoralne, zwane cnotami (aretes). Etyka chrześcijańska przejęła od Arystotelesa definicję cnoty jako „właściwego środka” (mesotes) pomiędzy skrajnościami nadmiaru i niedostatku ${ }^{29}$. Wydaje się, że Karol Wojtyła jako etyk zrozumiał ideę „właściwego środka”, przyjmując „dobro osoby” za właściwą miarę poszczególnych wartości. Także tzw. cnoty dianoetyczne, czyli zdolności intelektualne i naturalne człowieka są kształtowane poprawnie tylko wtedy, gdy uwzględnia się ich moralny cel. Podejście to zabezpiecza przed intelektualizmem czy moralizmem, włączając walory intelektualne i moralne w żywe i niepowtarzalne człowieczeństwo danej osoby.

Trzeba jednak pamiętać, że dla Wojtyły-etyka i Jana Pawła II-teologa, „dobro osoby" jest zawsze złożone z wartości tworzących relacje z ludźmi i z Bogiem. Starannie odróżniał on „prawdziwe dobro osoby” od iluzji indywidualizmu czy narcyzmu, bądź kolektywizmu i totalitaryzmu. Odrzucał też ateizm i agnostycyzm, zarzucając tym wszystkim nurtom „błąd antropologiczny” polegający na redukcjonistycznej wizji człowieka ${ }^{30}$. Był bowiem przekonany, iż należy „harmonijnie łączyć sprawy wiary, sprawy myślenia i sprawy serca. To nie są osobne obszary. Każdy przenika i ożywia pozostałe"31.

Wydaje się zatem, że profesor Hanna Świda-Ziemba celnie i zwięźle określiła rdzeń osobowości Karola Wojtyły - Jana Pawła II przez formułę „uosobienia wartości chrześcijańskich”. Tym samym wskazała na ostatni obszar badawczy, czyli katolicką teologię, której papież zawdzięczał zarówno teoretyczny projekt integralnego rozwoju, jak również własną formację.

Nie ma potrzeby wchodzenia tu w zawiłą i złożoną dyskusję na temat „wartości chrześcijańskich". Wystarczy proste stwierdzenie, że kryją się one w treści dwóch przykazań miłości Boga i bliźniego, złączonych nierozerwalną więzią i streszczających całą moralności objawioną Starego i Nowego Testamentu. Stoją one na straży dobra osoby ludzkiej, wskazując na poszczególne wartości, bez których dobro to nie jest prawdziwe ${ }^{32}$. Takie aksjologiczne podejście do biblijnego pojęcia „przykazanie" zostało wypracowane w katolickiej teologii w ostatnich latach, również

\footnotetext{
${ }^{28}$ Por. K. Wojtyła, Osoba i czyn oraz inne studia antropologiczne, dz. cyt., s. 195.

${ }^{29}$ Por. Arystoteles, Etyka nikomachejska II, 6, [w:] Arystoteles, Etyka nikomachejska. Etyka wielka. Etyka eudemejska. O cnotach $i$ wadach, tłum. D. Gromska, L. Regner, W. Wróblewski, Warszawa 2000, s. 111-113.

${ }^{30}$ Por. M. Zboralska, Przekraczanie siebie jako podstawa antropologii teologicznej Karola Wojtyły-Jana Pawła II, dz. cyt., s. 239.

${ }^{31}$ Jan Paweł II, Wstańcie, chodźmy!, Kraków 2004, s. 79.

${ }^{32}$ Por. Jan Paweł II, enc. Veritatis splendor, 13-14.
} 
pod wpływem Jana Pawła II ${ }^{33}$. Jego koncepcja współczesnej teologii moralnej zakłada bowiem najpierw głębokie doświadczenie wartości chrześcijańskiej, a następnie przyjęcie jej jako obiektywnej powinności/normy. Właśnie wtedy dokonuje się personalizacja wartości chrześcijańskich w pełnej formie, która otwiera możliwość stopniowego doskonalenia osobowości. Jest to przejście od tzw. „pierwszej wolności”, czyli uwolnienia od zła moralnego, do wolności „drugiej”. Polega ona na egzystencjalnej symfonii wewnętrznego usposobienia i konkretnych postaw, na które wskazują ewangeliczne „błogosławieństwa” oraz obiektywnych norm religijno-moralnych, które wydobywa się na drodze deontologicznej interpretacji biblijnych przykazań ${ }^{34}$. Wolność „druga” wprowadza człowieka na poziom chrześcijańskiego życia; staje się on wówczas „osobą”, która przekracza siebie ku Bogu i bliźnim. W oryginalnym języku Karola Wojtyły-Jana Pawła II oznacza to „komunię osób” poprzez bezinteresowny dar z samego siebie ${ }^{35}$, realizację oblubieńczego i rodzicielskiego sensu ciała, zdolność do tworzenia właściwych relacji interpersonalnych jak np. uczestnictwo, solidarność czy sprzeciw, przebaczenia, zwyciężania zła większym dobrem czy tzw. „wyobraźni miłosierdzia”36. Wszystkie te określenia zrodziły się z jego wnikliwej interpretacji chrześcijańskiej aksjologii, której punktem wyjścia jest stwierdzenie, iż wiara działa przez miłość (por. Ga 5, 6).

Wówczas też osiąga się wewnętrzną harmonię, zauważoną przez naszą autorkę w osobie Jana Pawła II. Jej trafne obserwacje zasługują więc na pamięć, gdyż w miarę upływu czasu, pytanie o osobowość papieża, staje się coraz bardziej interesujące. Kolejną racją uzasadniającą tę pamięć jest fakt, iż autorka postawiła jakby mimochodem, kwestię udanej personalizacji tej historycznej postaci. Tym samym wskazała na nowe perspektywy badania biografii człowieka tak znanego, iż wydaje się, że już całkowicie poznanego. I last but not least, przypomniany tekst na przykładzie sylwetki autorki i jej bohatera przedstawia model spotkania ludzi pozornie dalekich, a jednak tak bliskich w tym, co „nieredukowalne”: sacrum i humanum.

${ }^{33}$ Por. Papieska Komisja Biblijna, Biblia a moralność. Biblijne korzenie postępowania chrześcijańskiego, tł. R. Rubinkiewicz, Kielce 2009, nr 30.

${ }^{34}$ Por. Jan Paweł II, enc. Veritatis splendor, 15-22.

${ }^{35}$ Por. M. Zboralska, Przekraczanie siebie jako podstawa antropologii teologicznej Karola Wojtyły-Jana Pawła II, dz. cyt., s. 118-121.

${ }^{36}$ Por. M. Zboralska, Przekraczanie siebie jako podstawa antropologii teologicznej Karola Wojtyty-Jana Pawła II, dz. cyt., s. 153-157. 


\section{Abstract \\ The personality of John Paul II in a forgotten text by Professor Hanna Świda-Ziemba}

The article resembles the forgotten text of an outstanding Polish scientist, prof. Hanna Świda-Ziemba (1930-2012), written as her personal memory after the first pilgrimage of John Paul II to Poland in June 1979. It contains a very valuable attempt to characterize the personality of the Polish Pope. The author, who then describes herself as an agnostic, makes a very factual description, using her scientific competences in the field of psychology, sociology and pedagogy. She notes that the main trait of John Paul's personality is a rare usually harmony of psychologically contradictory properties. He is an outstanding intellectual, author of one of the few human philosophies in Poland, a spiritual man with strong religious and moral convictions. And at the same time a determined, cordial and warm person who can create deep relationships with people. H. Świda-Ziemba describes this phenomenon as "a natural personification of Christian values". And although he does not try to explain this phenomenon, he inspires others to such searches. Thus, it indicates that in the philosophical anthropology, ethics and theological teaching of K. Wojtyła-John Paul II there is a description of his own personalization.

Keywords: personality of John Paul II, philosophical and theological anthropology, ethics, moral theology, personalization, crossing oneself towards God and neighbor, virtue as a measure of the good of a person 